\title{
Sino-Russian Intercultural Communication Research: Literature Review
}

\author{
Ekaterina D. Vasilyeva, Nadezhda M. Lebedeva \\ National Research University Higher School of Economics \\ 4 Armyansky Lane, bldg. 2, Moscow, 101000, Russian Federation
}

\begin{abstract}
International relations between China and Russia have a long-lasting history. At the same time interpersonal contacts between these two ethnic groups face difficulties associated with language, cultural distance, prejudices and other factors. This article presents a review of studies on the problem of Russian-Chinese intercultural interaction. Due to its interdisciplinary nature the studies are scattered both methodologically and with respect to its theoretical foundations. In this regard, we conditionally divide the considered works into four main areas: studying the perception of the image of Russia and China among Russians and Chinese, classification of Sino-Russian communication barriers, cross-cultural analysis of communication components, and indigenous concepts of Chinese psychology related to the process of intercultural interaction. A brief review of the modern research results gained by Russian and Chinese authors on effective communication and building trustful relationships is given. The results of studies revealing important differences at the level of verbal and non-verbal communication are presented. Particular attention is paid to cross-cultural research aimed at identifying etic and emic attributes of the situation of intercultural interaction. The most common approaches to understanding the concept of trust and its operationalization in Chinese studies are described. The importance of further studying mechanisms of building trustful relationships between representatives of the two countries is noted. In conclusion, unresolved problems and current trends in the study of intercultural communication are identified.
\end{abstract}

Key words: intercultural communication, intercultural perception, indigenous concepts, cross-cultural research, Russia, China

\section{Introduction}

Studying the relationship between Russia and China has a long history. Changes associated with the geopolitical and economic situation affect the nature of bilateral relations. Despite the significant number of contacts between countries, the process of communication at the interpersonal level is often accompanied by cases of misunderstanding and passing communication barriers along the way (Croucher et al., 2015; Spencer-Oatey, 2017).

Theoretical elaboration of this problem is clearly interdisciplinary. In this regard, there is a need for a review and classification of existing works on the topic. 
The purpose of this article is to systematize the accumulated empirical work and identify unresolved problems and relevant areas for research in the field of intercultural communication between Russian and Chinese people.

Meta-analysis shows that intercultural communication between Russians and Chinese is studied at several levels: at the level of perception and mutual stereotypes (Block, 2013; Batkhina, 2019; Chen, 2008; Grigoryev et al., 2019), at the level of verbal and non-verbal communication (Martin, 2017; Spitzberg, 2013), at the level of differences in values and communication styles (Harrison, 2009; Henze, 2012; Leung, 2015; Stephan, 2014; Winkler, 2008), as well as at the level of indigenous components of Chinese communication (Bond, 2010; Ting-Toomey, 2005; Yuan, 2011). Based on this, in this review, studies of Russian and foreign authors are conventionally divided into four main categories: perception of the image of Russia and China, classification of communication barriers between Russians and Chinese, cross-cultural analysis of communication components, and indigenous concepts of Chinese psychology related to the process of intercultural interaction.

\section{Studying the perception of the image of Russia and China}

At this stage, the "Chinese vector" of Russian foreign policy stimulates the desire to analyze relationships at the national level (Zuenko, 2017; Malle, 2017; Wilson, 2015; Røseth, 2016). For example, a separate niche is occupied by works in the field of imagology, the subject of which is how our countries see each other (Tikhvinsky, 2008; Ten, 2012; Stronski, 2018; Tremin, 2012).

At the same time, social psychology has a developed methodologies for identifying features of the processes of social perception at the level of large social groups. Within this area, there is a tradition of studying subjective culture, which determines how individuals categorize social objects, highlight the links between categories and which categories they recognize as "their own". Subjective culture embraces all representations, beliefs and ideas that unite people and have a direct impact on their behavior and activities (Stefanenko, 2009).

In her study, T. Stefanenko conducted a cross-cultural analysis of ideas about Russia among Russian students and students from the USA and China countries influential from the point of view of Russians. The results show that in the view of the Chinese respondents, Russia primarily is a country "rich" in natural resources and the military-industrial complex, but not people (since it is perceived as "sparsely populated"). At the same time, students studying in China, focus more on natural resources and climatic conditions, and broader, "cultural" associations arise among students studying in Russia. In addition, students studying in China demonstrate more superficial knowledge of Russia (Stefanenko, 2012).

A study of the image of China in Russia (Lukin, 2003) shows that this is a complex system that includes numerous sub-images of China, for example, in various regions of Russia and among various population groups. The image of another country is more stable than other views, since the main external factors influencing it - geographical location, size, power and population of the two countries remain unchanged or approximately the same over long historical periods.

S. Kononov writes that Russians' perception of China is based on two main opposing views, which are based on the assessment of China's influence on Rus- 
sia. The first group is "alarmists," indicating dangerous trends in Russian-Chinese interaction, and the second is "pragmatists," which form images calming mass consciousness. These data show how unverified, and based solely on faith, is the perception of the image of China at the level of mass consciousness (Kononov, 2016).

These results reflect the ideas that guide representatives of our countries during communication. It is especially worth noting revealed stability of these ideas and the influence of a wider context on them (Spencer-Rodgers, 2002).

Both at the level of state relations and at the level of business communication, difficulties arise due to a lack of trust between representatives of the two countries (Røseth, 2016). Carlsson explains this with uncertainty about the true intentions of the counterpart. Moreover, while at the state level, the reasons are the geopolitical interests of the two countries, then at the level of interpersonal communication, the true reasons for this distrust are still to be studied.

\section{Identification and typology of Russian-Chinese communication barriers}

Moving to the level of interpersonal communication between the representatives of the two countries, the researchers analyze the psychological difficulties and factors that can affect the effectiveness of this interaction.

Khunyue divides the causes of communicative failures into 3 groups. The first group is the wrong choice of a language unit and discursive strategy, as well as incorrect interpretation of its meaning. The author identifies 3 types of discursive errors:

- "etiquette" errors due to ignorance of speech etiquette rules;

- "stereotypical" errors caused by ignorance of Russian sociocultural stereotypes of verbal communication;

- "encyclopedic" errors due to insufficient amount of acquired background knowledge.

The second group is errors related to cultural traditions, and the third group is errors related to the momentary context: features of the situation, emotional state (Khunyue, 2017).

Social psychologist P. Yakupov identifies several barriers to RussianChinese interaction: excessive closed nature of the Chinese in communication; desire for a vertical structure of organization; and syncretic understanding of time space. It is these features that are in dichotomy with the behavior of the representatives of the Russian business environment that the Chinese respondents pointed out, namely: excessive openness in communication, desire for a horizontal structure of organization, and a clear division of time space (Yakupov, 2017).

Quite interesting for cross-cultural analysis is comparison of non-verbal communication methods. However, the classification in most cases is based on the analysis of literature and observations. For example, A. Savvin notes such dominant features of non-verbal communication as rapport and greater freedom of action among Russians, while among the Chinese - rapport and open manifestation of emotions. At the same time, the Chinese gesticulation is characterized by lower frequency, a relatively small amplitude of movements and more restraint than the Russian gesticulation (Savvin, 2015).

I. Novikova and M. Gridunova analyzed the perception of non-verbal behavior of the Chinese in the process of interaction with Russians. Based on the results of 
the analysis, she comes to the conclusion that this perception is much more stereotyped than the perception of Russian non-verbal communication by Chinese students. Most likely because, while studying in Russia, they have the opportunity of real communication with representatives of the host society, where stereotypes are verified and destroyed.

In addition, the results of the study allow authors to conclude that, compared with Chinese students, Russian students tend to interact more effectively with people who behave in accordance with the stereotypes of their own ethnic group's non-verbal behavior. Chinese students, unlike Russian students, have the opposite tendency - towards more effective interaction with people, whose non-verbal behavior is more similar to Chinese (Novikova, Gridunova, 2011).

Zhang Yifan's work provides an analysis of Russians' perceptions of the specifics of verbal and non-verbal behavior of Chinese people. The methodlogy of free and directed associative experiment revealed that Russians note the complexity of the Chinese language and everyday smiling of the Chinese. Assessment of business and personal qualities of the Chinese is positive, and their appearance is neutral. The analysis of proverbs showed that the lexeme "Chinese" is part of three Russian phraseological units: "Wall of China", "Chinese ceremonies", and "Chinese letter". The author comes to the conclusion that Russians have historically perceived the Chinese society as closed, having a complex writing system and an extensive repertoire of etiquette forms (Zhang, 2016).

$K$. Fedorova studied the problems of interethnic interaction on the border of Russia and China - in the Trans-Baikal Territory and Inner Mongolia. The main conclusion of this work is the fact that the same speech patterns, stereotypes and attitudes have been preserved in this region for decades. At the language level, the following picture is observed: it is the Chinese who are trying to master the Russian language, and not vice versa. However, due to heavy accent, their status in the eyes of the Russian population is not very high. Thus, negative stereotypes regarding the Chinese persist and destructively affect communication and relations between two ethnic groups (Fedorova, 2012).

\section{Cross-cultural analysis of communication components}

Many studies focus on the search for universals and differences in the psychology of representatives of the two peoples. We will look at some studies conducted on the Russian and Chinese samples that are directly related to communication, especially in the business environment.

O. Bychikhina, in the context of studying ways to build trusting relations between Russians and Chinese, compares two styles of negotiating according to criteria: intonation, purpose of communication, communication dominants, main source of information, business strategies, and features of communication (Table 1).

N. Lebedeva writes that the relations of values and attitudes towards innovations are both universal and culturally specific, due to the value priorities of the members of a given culture and the implicit theories of creativity present in these cultures. Intercultural differences in the values of Russian and Chinese students are as follows: Russian students prefer the values of openness to change and self-affirmation more, and Chinese students prefer the values of conservation and leap of trust. The revealed differences, according to the author, reflect differences 
along the line of "traditionalism - modernism", where Chinese culture is closer to the pole of traditionalism, while Russian culture on this continuum is closer to the pole of modernization (Lebedeva, 2007).

Table 1

Comparison of Chinese and Russian approach to business communication

(Bychikhina, 2014. P.161)

\begin{tabular}{|c|c|c|}
\hline Criteria & Chinese approach & Russian approach \\
\hline Intonation & Quiet & Loud \\
\hline Aim & Step-by-step gain & "All or nothing" \\
\hline $\begin{array}{l}\text { Communication } \\
\text { dominant }\end{array}$ & Indirect, subjunctive & Direct, imperative \\
\hline $\begin{array}{l}\text { Main information } \\
\text { source }\end{array}$ & Non-verbal means & Verbal means \\
\hline \multirow{5}{*}{$\begin{array}{l}\text { Business } \\
\text { strategies }\end{array}$} & 1. Saving face & 1. Sincerity \\
\hline & 2. Infiniteness & 2. Definiteness \\
\hline & 3. Flexibility and compromise & 3. The winner takes it all \\
\hline & 4. Patience & 4. Saving time \\
\hline & 5. Partners' social status & 5. Task fulfillment \\
\hline \multirow{5}{*}{$\begin{array}{l}\text { Communication } \\
\text { features }\end{array}$} & 1. Indirect & 1. Indirect \\
\hline & 2. Introversion, self-control & 2. Extraversion, impulsivity \\
\hline & 3. Personality-oriented & $\begin{array}{l}\text { 3. Depersonalization (team spirit, coope- } \\
\text { ration) }\end{array}$ \\
\hline & 4. Lack of physical contact & $\begin{array}{l}\text { 4. Existence and acceptability of physi- } \\
\text { cal contact }\end{array}$ \\
\hline & 5. Gestures seldom used & $\begin{array}{l}\text { 5. Gestures make sense and are often } \\
\text { used }\end{array}$ \\
\hline
\end{tabular}

A separate cohort of studies is devoted to the features and comparison of building trusting relationships in Russia and China. One of the important aspects in both cases is the participation of third parties, as an intermediary in communication, or their recommendations. Empirical studies on this topic have been conducted in the field of investment (Batjargal, 2007). The work of D. Batjargal refers to the fact that the interpersonal trust of the investor and the intermediary leads to a decision in favor of investing, therefore the "three-party" connections, or triads, are most effective. This confirms the theory that in particularistic societies, interpersonal trust plays a much greater role than general social or institutional trust (Xin, 1996; Batjargal, 2003).

The study of L. Grigoryan and N. Lebedeva verifies the cultural universality of the structure of informal ties in an organization in a sample of five countries, including Russia and China. The study relies on a three-component model of guan$\mathrm{xi}$, specific to Chinese culture, where the structure of informal ties includes such components as emotional attachment, involvement in personal life and reverence for the leader (Grigoryan, 2013).

A study by A. Ardichvili is devoted to the perception of corporate culture based on the material of five countries, including Russia and China (Ardichvili, 2012). The results suggest that the perception of corporate culture in these two countries differs from other BRICS countries - India, Brazil and South Africa. The latter had indicators higher on all five scales of perception of corporate culture: trust 
and honesty in relation to the organization, management efficiency, mission and values, balance of stakeholders, integrity and transparency of processes.

S. Michailova studied the similarities and differences in the individual style of knowledge sharing behavior in Russian and Chinese organizations. She writes that employees of Chinese companies exchange information within the group in such a way as to comply with the group's interests and preserve the face of the group. At the same time, employees of Russian companies share information in pursuit of individual interests. At the same time, in both cases, the main goal is protection from representatives of the outer group and, sometimes, even aggression towards its representatives (Michailova, 2016).

Today two main features of studies of the two countries' representative's interaction are worth mentioning: firstly, diversity of research methods, and secondly, apparent predominance of research in line with the indigenous direction. Ethnopsychological studies of Russian and foreign authors, devoted to indigenous concepts of Chinese psychology and communication theory, prevail in the research literature. This state of affairs has developed since the publication in 1894, of Arthur Smith's famous book "Chinese Characteristics," the first chapter of which is called "The Face." Subsequently, it was this phenomenon that became one of the key and most studied in psychology (Smith, 1894). At the present stage of development of Chinese indigenous psychology, two basic concepts - the Guanxi informal relationship system and the Mianzi face concept - have given impetus to the development of whole areas of research (Bond, 2010).

\section{Features of Chinese communication style}

Continuing the theme of indigenous concepts in Chinese psychology and communication theory, a small outline of the trends that have emerged in the literature on the Chinese style of communication in recent years should be made. Chinese traditional communication style, based on Confucian values, has undergone some changes due to the development of China in recent decades. Modern communication retains its traditional features, but at the same time acquires new characteristics. In general, the combination of these two styles can be compared with the concept of Yin-Yang, or the unity of opposites, which also lies at the very foundation of Chinese psychology (Fang, 2011).

Five main characteristics of Chinese communication are usually highlighted (Gao et al., 2010): indirect communication (含蓄 hanxu), listening orientation (听 话 tinghua), politeness (客气 keqi), priority of maintaining communication within the group (自己人 zijiren), and saving face (面子 mianzi). These five characteristics are based on Confucian values, but the dual nature of communication, the philosophy of which is rooted in the teachings of Taoism and the unity of the opposites of Yin and Yang, is not taken into account (Chen, 2008). This approach may explain why, in the eyes of a foreigner, a Chinese negotiating partner can be closed, formal, categorical on the one hand, and can be open, informal and ready for compromise on the other. In the Chinese language and in the culture as a whole, the idea that everything contains an opposite is the basic one. For example, the twosyllable word “things" 东西 dongxi consists of the characters 东 dong - “east" and 西 
$x i$ - "west"; another example relevant to the business environment: “crisis" 危机 weiji consisting of two characters - “danger" 危 wei and “opportunities”机 $j i$.

Fang notes that for this reason the Chinese do not have any cognitive dissonance about phrases linguistically baffling the English-speaking person, for example, the terms "socialist market economy", "one country - two systems", or "stable development”. These English-language variants are very competently localized into the Russian language, for example, "socialism with Chinese characteristics", and at least at the language level they do not sound like an oxymoron. Further, the author extends the traditional characteristics of communication, introduces a dichotomy to each of them, thus emphasizing the paradox of the modern culture of communication, which includes both Confucian values and norms of communication that were formed in modern times.

For example, no one would argue that the concept of the face is the central regulator in the behavior of the Chinese. This implies taking care not to "lose face yourself" and not to harm the face of your vis-a-vis. At the same time, in Taoism there is a concept-antipode, that is, the idea of a "thick face" (Chu, 1992). From the point of view of Taoism, having the courage to lose face, a person becomes psychologically stronger and more mature. In a situation of defeat or loss of dignity, the best strategy, according to Taoists, is not to stand your ground, but to retreat in order to return later and again "build face" (Fang, 1999).

The dual nature of communication, the "quadrature of the Chinese circle" (Myasnikov, 2006), is one of the most important reasons why such convenient instructions of "Do's and Taboos" during negotiations with Chinese partners often fail in practice. Of much greater benefit, and this is evident from the research literature of recent years, is building trusting bilateral relations.

For a deeper understanding of this process, it is important to consider the concept of trust in Chinese culture.

Wang proposes five types of trust:

1. Trust between relatives. This is the type of relationship that does not build up over time, but is present throughout life. Therefore, the risk factor as such is absent or ignored in the perception of loved ones.

2. Accumulated trust based on individual qualities and behavior and appears with experience in communication. The simplest example is mutual trust between friends, which comes from emotional attachment and a sense of belonging.

3. A priori trust is the most unreliable and ephemeral type. It implies the historically established or enshrined in the language of confidence in certain phenomena, things and people. For example, folklore can be the source of such trust, therefore it is impossible to somehow measure or predict it.

4. Professional trust - means trust in competent professionals in their field. As a rule, these are professions whose professionalism is easiest to evaluate from your own experience - doctors, teachers and lawyers. At the same time, the general "accumulated" authority of these specialists automatically provides in the future a higher level of trust in them.

5. Institutional trust. Its source is the calculation of personal gain. This is the type of trust that is necessary to build relationships outside of the Guanxi system, following written and unwritten rules. In this case, the ratio of possible risks and benefits from these relationships plays a large role (Wang, 2018). 
Wang says that the institutional type of trust is related to cognitive trust, while the accumulated trust - to affective (Wang et al., 2006).

Table 2

Characteristics of five types of Trust (Wang, 2018)

\begin{tabular}{|c|c|c|c|c|c|}
\hline & \multicolumn{2}{|c|}{ In-group (inside Guanxi group) } & \multicolumn{3}{|c|}{ Out-group (outside Guanxi group) } \\
\hline & $\begin{array}{l}\text { Trust between } \\
\text { relatives }\end{array}$ & $\begin{array}{c}\text { Accumulate } \\
\text { trust }\end{array}$ & $\begin{array}{l}\text { A priori } \\
\text { trust }\end{array}$ & $\begin{array}{c}\text { Professional } \\
\text { trust }\end{array}$ & $\begin{array}{c}\text { Institutional } \\
\text { trust }\end{array}$ \\
\hline Basis & Relatives' ties & $\begin{array}{c}\text { Emotional } \\
\text { attachment }\end{array}$ & Tradition & $\begin{array}{c}\text { Knowledge, } \\
\text { skills, abilities }\end{array}$ & $\begin{array}{l}\text { Interests, } \\
\text { gain }\end{array}$ \\
\hline $\begin{array}{l}\text { Mecha- } \\
\text { nism }\end{array}$ & Guanxi & Identity & Historical context & Logics & Assumption \\
\hline Form & $\begin{array}{c}\text { Life } \\
\text { consequences }\end{array}$ & Promise & $\begin{array}{c}\text { Experience, } \\
\text { public opinion }\end{array}$ & $\begin{array}{c}\text { License } \\
\text { (document } \\
\text { confirming } \\
\text { professionalism) }\end{array}$ & $\begin{array}{l}\text { Agreement, } \\
\text { law }\end{array}$ \\
\hline Support & Own initiative & Reciprocal & Practice & Analysis & $\begin{array}{c}\text { Documentation/ } \\
\text { ethics }\end{array}$ \\
\hline Risks & None & $\begin{array}{l}\text { Assessed } \\
\text { subjectively }\end{array}$ & $\begin{array}{c}\text { Assessed } \\
\text { heuristically }\end{array}$ & Predictable & $\begin{array}{c}\text { Assessed } \\
\text { relatively } \\
\text { objectively } \\
\end{array}$ \\
\hline $\begin{array}{l}\text { Expecta- } \\
\text { tions }\end{array}$ & High & High/medium & Medium & Low & Low \\
\hline $\begin{array}{l}\text { Change- } \\
\text { ability }\end{array}$ & None & Partially & Optionally & Optionally & Optionally \\
\hline Duration & Permanent & Long & Partial & Flexible & Temporary \\
\hline
\end{tabular}

Understanding mechanisms of building trusting relationships is extremely important in the context of intercultural communication. Since it is precisely the very basic component for tolerant attitude towards representatives of another culture. In the absence of trust, we are no longer talking about tolerance, as the ability to openly relate to otherness, but about assertiveness. In contrast to tolerance based on trust in another person, assertiveness is caused by distrust towards a communication partner, so interaction is significantly complicated. Assertive behavior is based on the following techniques:

1) insisting on your rights, interests, opinions and values;

2) clear distribution of responsibilities between partners, which has to be formalized in written agreements, instructions, etc.;

3) friendly, sincere and open behavior, which can contribute to the transition to trustful communication;

4) manifestation of readiness for cooperation, search for common interests and prospects for further joint work (Pochebut, 2017).

We see that in this case we are talking about another set of skills necessary for intercultural communication. Thus, the question of how trust is formed in Russian and Chinese culture is the key to understanding what kind of knowledge and skills are necessary for successful communication between our countries.

\section{Conclusion}

A review of studies on Russian-Chinese intercultural interaction allows us to draw several conclusions. 
A great influence on the communication process is provided by the perception of the Chinese by Russians and vice versa. To a large extent, it is formed by a wide context - a stable system of ideas about another country, due to the geopolitical situation, geography, and economic situation. This forms stereotypes and attitudes that have not changed for decades.

A review of literature shows that differences in the level of values, in communicative behavior and prevailing stereotypes also affect mutual trust of representatives of the two countries and the desire to interact.

Since the field of intercultural communication is interdisciplinary in nature, one of the areas for the development of this field is the integration of methodological and theoretical framework.

Throughout the history of intercultural communication as a separate scientific field, the practical significance of research results has been put at the forefront. The development of intercultural sensitivity is seen as the main tool in overcoming existing difficulties and developing harmonious interaction between representatives of Russia and China. A large role in the development of this direction belongs to the famous Russian ethno-psychologist T. Stefanenko, who was one of the first to study this complex and interesting problem.

Acknowledgements and Funding. The article was prepared within the framework of the HSE University Basic Research Program.

\section{References}

Ardichvili, A., Jondle, D., Kowske, B., Cornachione, E., Li, J., \& Thakadipuram, T. (2011). Ethical Cultures in Large Business Organizations in Brazil, Russia, India, and China. Journal of Business Ethics, 105(4), 415-428. http://doi:10.1007/s10551-011-0976-9

Batjargal, B. (2007). Internet entrepreneurship: Social capital, human capital, and performance of Internet ventures in China. Research Policy, 36(5), 605-618.

Batkhina, A.A., \& Lebedeva, N.M. (2019). Predictors of behavioral strategy choice among Russians in intercultural conflict. Social Psychology and Society, 10(1), 70-91. http://doi.org/10.17759/sps.2019100105

Block, D. (2013). The structure and agency dilemma in identity and intercultural communication research. Language and Intercultural Communication, 13(2), 126-147. doi.org/10.1080/14708477.2013.770863

Bond, M.H. (Ed.). (2010). The Oxford Handbook of Chinese Psychology. Oxford: Oxford Library of Psychology.

Bychikhina, O.V. (2014). Analiz osnovnyx kommunikativnyx modelej rossijskogo i kitajskogo biznes-diskursov. Vestnik Novosibirskogo Gosudarstvennogo Pedagogicheskogo Universiteta, 5(21). (In Russ.)

Chen, Guo-Ming. (2008). Bian (Change): A Perpetual Discourse of I Ching. Intercultural Communication Studies, 17(4), 7-16.

Chu, C.N. (1992). Thick Face, Black Heart: The Path to Thriving, Winning \& Succeeding. Warner Books.

Croucher, S.M., Sommier, M., \& Rahmani, D. (2015). Intercultural communication: Where we've been, where we're going, issues we face. Communication Research and Practice, 1(1), 71-87. doi.org/10.1080/22041451.2015.1042422

Fang, T., \& Faure, G.O. (2011). Chinese communication characteristics: A Yin Yang perspective. International Journal of Intercultural Relations, 35(3), 320-333. doi.org/10.1016/j.ijintrel.2010.06.005 
Fedorova, K. (2012). Transborder trade on the Russian-Chinese border: Problems of interethnic communication. In B. Bruns \& J. Miggelbrink (Eds.), Subverting Border (pp. 107-128). Wiesbaden: VS Verlag für Sozialwissenschaften. https://doi.org/10.1007/9783-531-93273-6 6

Gao, H., Ballantyne, D., \& Knight, J.G. (2010). Paradoxes and guanxi dilemmas in emerging Chinese - Western intercultural relationships. Industrial Marketing Management, 39(2), 264-272. https://doi.org/10.1016/j.indmarman.2008.11.001

Grigoryan, L.K., \& Lebedeva, N.M. (2013). Informal ties in organization: is it culture-specific or culture-universal phenomenon? Organizational Psychology, 3(1). (In Russ.)

Grigoryev, D., Fiske, S.T., \& Batkhina, A. (2019). Mapping Ethnic Stereotypes and Their Antecedents in Russia: The Stereotype Content Model. Frontiers in Psychology, 10. https://doi.org/10.3389/fpsyg.2019.01643

Harrison, N., \& Peacock, N. (2009).Cultural distance, mindfulness and passive xenophobia: Using Integrated Threat Theory to explore home higher education students' perspectives on 'internationalisation' at home. British Educational Research Journal, 36, 877-902. https://doi.org/10.1080/01411920903191047

Henze, J., \& Zhu, J. (2012). Current Research on Chinese Students Studying Abroad. Research in Comparative and International Education, 7(1), 90-104. https://doi.org/10.2304/rcie.2012.7.1.90

Khunyue, Sh. (2017). Kommunikativnye Neudachi v Mezhkul'turnoi Kommunikatsii. PhD Thesis. Chelyabinsk: South Ural State University. (In Russ.)

Kononov, S.V. (2016). Razvitie nauchnogo diskursa o vospriyatii obraza Kitaya v rossiiskokitaiskom prigranich"e. Sovremennye Tendentsii Razvitiya Nauki i Tekhnologii, (2-1), 130-135. (In Russ.)

Lebedeva N.M., Chirkov V.I., \& Tatarko A.N. (2007). Kul'tura i Otnoshenie k Zdorov'yu: Rossiya, Kanada, Kitai. Moscow: RUDN University Publ. (In Russ.)

Lebedeva, N.M. (2011). Etnicheskaya i Kross-Kul'turnaya Psikhologiya. Moscow: MAKS Press. (In Russ.)

Leung, K., \& Morris, M.W. (2015). Values, schemas, and norms in the culture-behavior nexus: A situated dynamics framework. Journal of International Business Studies, 46(9), 1028-1050. https://doi.org/10.1057/jibs.2014.66

Lukin, A. (2003). Evolyutsiya obraza Kitaya v Rossii i rossiisko-kitaiskie otnosheniya. Neprikosnovennyi Zapas, (3), 29. (In Russ.)

Martin, J.N. (2017). Dialectics of Culture and Communication. The International Encyclopedia of Intercultural Communication (pp. 1-6). Chichester: Wiley-Blackwell. doi.org/10.1002/9781118783665.ieicc0215

Michailova, S., \& Hutchings, K. (2016). National cultural influences on knowledge sharing: A comparison of China and Russia. Journal of Management Studies, 43(3), 383-405. https://doi.org/10.1111/j.1467-6486.2006.00595.x.

Myasnikov, V.S. (2006). Kvadratura Kitaiskogo Kruga. Moscow: Nauka Publ. (In Russ.)

Novikova, I.A., \& Gridunova, M.V. (2011). Cross-cultural differences of stereotypes: nonverbal communication of Russian and Chinese students. RUDN Journal of Psychology and Pedagogics, (3), 40-45. (In Russ.)

Pochebut, L.G., \& Beznosov, D.S. (2017). Assertiveness and tolerance in cross-cultural interaction. Social Psychology and Society, 8(3), 8. https://doi.org/10.17759/sps.2017080302 (In Russ.)

Røseth, T. (2016). China and Russia - A study on Cooperation, Competition and Distrust. Nordisk Østforum, 30(1). https://doi.org/10.17585/nof.v30.398

Savvin, A.N., \& Savvina, K. S. (2015). Sopostavlenie russkikh, yakutskikh, angliiskikh i kitaiskikh neverbal'nykh sredstv obshcheniya kak odin iz sposobov formirovaniya lingvokul'turnoi kompetentnosti. Aktual'nye Napravleniya Nauchnykh Issledovanii: ot Teorii k Praktike, (2), 167-170. (In Russ.) 
Smith, A.H. (1894). Chinese Characteristics. New York; Chicago: Fleming H. Revell Company. Spencer-Oatey H., \& Dauber, D. (2017). The gains and pains of mixed national group work at university. Journal of Multilingual and Multicultural Development, 38(3), 219-236. https://doi.org/10.1080/01434632.2015.1134549

Spencer-Rodgers, J., \& McGovern, T. (2002). Attitudes toward the culturally different: The role of intercultural communication barriers, affective responses, consensual stereotypes, and perceived threat. International Journal of Intercultural Relations, 26(6), 609-631. https://doi.org/10.1016/s0147-1767(02)00038-x

Spitzberg, B.H. (2013). (Re)Introducing communication competence to the health professions. Journal of Public Health Research, 2(3), 23. https://doi.org/10.4081/jphr.2013.e23_

Stefanenko, T.G. (2009). Etnicheskaya identichnost': ot etnologii k sotsial'noi psikhologii. Vestnik Moskovskogo Universiteta. Seriya 14: Psikhologiya, (2), 3-17. (In Russ.)

Stefanenko, T.G. (2013). Etnopsikhologiya. Moscow: Aspekt Press Publ. (In Russ.)

Stefanenko, T.G., Malysheva, N.G., \& Tikhomandritskaya, O.A. (2012). Obraz Rossii v mnogopolyarnom mire: kross-kul'turnyi analiz. Vestnik Moskovskogo Universiteta. Seriya 14: Psikhologiya, (1), 61-73. (In Russ.)

Stephan, W.G. (2014). Intergroup Anxiety: Theory, Research, and Practice. Personality \& Social Psychology Review, 18(3), 239-255. https://doi.org/10.1177/1088868314530518

Ting-Toomey, S. (2005). The matrix of face: An updated face-negotiation theory. In W.B. Gudykunst (Ed.), Theorizing about Intercultural Communication (pp. 71-92). Thousand Oaks, CA: Sage.

Wang, Q., Clegg, J., Gajewska-De Mattos, H., \& Buckley, P. (2018). The role of emotions in intercultural business communication: Language standardization in the context of international knowledge transfer. Journal of World Business, 100973. https:/doi:10.1016/j.jwb.2018.11.003

Wang, Y.W., Chen, L.C., \& Hwang, K.K. (2006). The strategies of trust in Chinese society. Indigenous Psychological Research in Chinese Societies, 25, 199-242.

Winkler, J.K., Dibbern, J., \& Heinzl, A. (2008). The impact of cultural differences in offshore outsourcing-Case study results from German - Indian application development projects. Information Systems Frontiers, 10(2), 243-258. https://doi.org/10.1007/s10796-008-9068-5

Yakupov, P., \& Chizhikova, N. (2017). Practical recommendations for overcoming ethnocultural barriers in communication between representatives of Russian and Chinese ethnos. Vestnik Universiteta, (7-8), 199-204. (In Russ.)

Yuan, W. (2011). Academic and cultural experiences of Chinese students at an American university: A qualitative study. Intercultural Communication Studies, 20(1), 141-157.

Zhāng, I., \& Ruzhentseva, N. (2016). Communicative behavior of the Chinese: as understood by the native Russian speakers. Pedagogical Education in Russia, 11, 89-95 (In Russ.)

\section{Article history:}

Received: 26 December 2019

Revised: 10 January 2020

Accepted: 25 January 2020

\section{For citation:}

Vasilyeva, E.D., \& Lebedeva, N.M. (2020). Sino-Russian Intercultural Communication Research: Literature Review. RUDN Journal of Psychology and Pedagogics, 17(1), 51-63. http://dx.doi.org/10.22363/2313-1683-2020-17-1-51-63

\section{Bio notes:}

Ekaterina D. Vasilyeva, MA in Linguistics, is a Ph.D. student of the Centre for Sociocultural Research, National Research University Higher School of Economics (HSE University) (Russia, Moscow). ORCID iD: 0000-0002-7814-953X, ResearcherID: X-81852018. E-mail: edvasilyeva@hse.ru 
Nadezhda M. Lebedeva, Doctor of Sciences in Social Psychology, is Tenured Professor, Director of the Centre for Sociocultural Research, National Research University Higher School of Economics (HSE University) (Russia, Moscow). ORCID iD: 0000-0002-20464529, ResearcherID: H-4866-2015, Scopus AuthorID: 8719892500. E-mail: nlebedeva@hse.ru

\title{
Обзорная статья
}

\section{Опыт изучения российско-китайской межкультурной коммуникации: обзор исследований}

\author{
Е.Д. Васильева, Н.М. Лебедева
}

Национальный исследовательский университет «Высшая школа экономики» Российская Федерация, 101000, Москва, Армянский пер., д. 4, стр. 2

Аннотация. В статье представлен обзор исследований, посвященных проблеме российско-китайского межкультурного взаимодействия. За счет ярко выраженного междисциплинарного характера данной проблемы, посвященные ей исследования разрозненны как в методологическом плане, так и в отношении теоретических оснований. В связи с этим мы условно делим рассматриваемые работы на четыре основных направления: изучение восприятия образа России и Китая среди русских и китайцев, классификация барьеров коммуникации между русскими и китайцами, кросс-культурный анализ компонентов коммуникации, индигенные концепции китайской психологии, связанные с процессом межкультурного взаимодействия. Приводится краткий обзор результатов современных исследований российских и китайских авторов, посвященных эффективной коммуникации и выстраиванию доверительных отношений. Приводятся результаты исследований, выявляющих важные различия на уровне вербальной и невербальной коммуникации. Особое внимание уделено кросс-культурным исследованиям, направленным на выявление культурно-специфичных и универсальных атрибутов ситуации межкультурного взаимодействия. Описываются наиболее распространенные в китайских исследованиях подходы к пониманию концепции доверия и ее операционализации. Отмечается важность дальнейшего изучения механизмов выстраивания доверительных взаимоотношений между представителями двух стран. В заключении обозначаются нерешенные проблемы и актуальные направления в области изучения межкультурной коммуникации.

Ключевые слова: межкультурная коммуникация, межгрупповое восприятие, индигенные концепции, кросс-культурные исследования, Россия, Китай

Благодарности и финансирование. Статья подготовлена в результате проведения исследования в рамках Программы фундаментальных исследований Национального исследовательского университета «Высшая школа экономики» (НИУ ВШЭ).

\section{История статьи:}

Поступила в редакцию: 26 декабря 2019 г.

Принята к печати: 25 января 2020 г. 


\section{Для цитирования:}

Vasilyeva E.D., Lebedeva N.M. Sino-Russian Intercultural Communication Research: Literature Review // Вестник Российского университета дружбы народов. Серия: Психология и педагогика. 2020. Т. 17. № 1. С. 51-63. http://dx.doi.org/10.22363/23131683-2020-17-1-51-63

\section{Сведения об авторах:}

Васильева Екатерина Дмитриевна, аспирант, стажер-исследователь Центра социокультурных исследований Национального исследовательского университета «Высшая школа экономики» (Москва, Россия). ORCID iD: 0000-0002-7814-953X, ResearcherID: X-8185-2018. E-mail: edvasilyeva@hse.ru

Лебедева Надежда Михайловна, доктор психологических наук, профессор, директор Центра социокультурных исследований Национального исследовательского университета «Высшая школа экономики» (Москва, Россия). ORCID iD: 0000-0002-20464529, ResearcherID: H-4866-2015, Scopus AuthorID: 8719892500. E-mail: nlebedeva@hse.ru 